\title{
Japansk politik står $i$ vejen for en \\ klarere japansk profil
}

Af Asger Røjle Christensen

Japans skiftende regeringer har $\mathrm{i}$ mange år gerne villet hæve landets udenrigspolitiske, sikkerhedspolitiske og militære profil i den store verden. Det gælder ikke mindst den nuværende regering under premierminister Shinzo Abe, den mest konservative og nationalistiske regeringschef, Japan har haft i mange år.

Mange spydige analytikere i såvel indland som udland har gennem årtierne kaldt Japan for en økonomisk kæmpe, men en politisk dværg, men sådan skal det ikke være længere, mener Shinzo Abe, som har fået nationalismen og drømmen om en mere selvstændig japansk ageren på den globale politiske scene ind med modermælken. Hans morfar var premierminister i 1960'erne, og hans far var udenrigsminister i 1980 'erne, og begge var kendt for at have den samme drøm.

Men det barokke er, at Japan i dag sagtens kunne spille en langt mere afgørende regional hovedrolle, end landet $\mathrm{g} ø \mathrm{r}$, hvis det ikke netop var for den udenrigspolitik, som samme Shinzo Abe og hans regering fører på flere felter. Den forværrer og fastholder den isolation fra det Øvrige Østasien, som Japan har måttet leve med i det meste af efterkrigstiden.

Der var mange gode historiske årsager til, at Japan gennem det meste af den kolde krig lå som en isoleret del af 'Vesten' langt mod øst. Der var så godt som ingen udvekslinger af mellemfolkelig art med det kommunistiske Kina og heller ikke med de to på hver sin måde diktatoriske koreanske stater.

\section{Yoshida-doktrinen}

Japan levede sit eget liv og koncentrerede sig med stor succes om at genopbygge $\sin ø$ konomi og give befolkningen, især i byerne, en levestandard, de aldrig før havde haft. Det skete under en såkaldt atomparaply, en militær be- 
skyttelse, som USA gav landet som et led i de omstridte amerikansk-japanske sikkerhedsaftaler, der blev indgået i 1960 og fornyet i 1970.

Japan var selv af den såkaldte fredsforfatning, som idealistiske medlemmer af de amerikanske besættelsesstyrker havde udstyret landet med i 1947, forhindret $i$ at have et rigtigt militær og måtte nøjes med militært udstyrede 'selvforsvarsstyrker'. Japanerne havde derfor efter afvæbningen ikke ret megen gammeldags 'hård magt' at komme med.

Ifølge den såkaldte Yoshida-doktrin, navngivet efter den konservative, men pragmatiske regeringschef Shigeru Yoshida, der stod i spidsen for den japanske regering fra 1946 til 1947 og igen fra 1948 til 1954, var det en god ting for japanerne at holde sig væk fra den øvrige verdens ufred, mens de koncentrerede sig om deres egen økonomiske butik og deres egne undertrykte efterkrigsdepressioner.

Der udviklede sig efterhånden en bred konsensus blandt almindelige japanere, både blandt pacifister (groft sagt på den politiske venstrefløj) og nationalister (groft sagt på den politiske højrefløj), om, at denne isolation faktisk var en god ting for Japan.

Krigen var ikke langt væk i erindringen, og med Yoshida-doktrinen og fredsforfatningen var man i det mindste ude i familierne sikre på, at de unge drenge, der voksede op efter babyboomet i begyndelsen af halvtredserne, aldrig som deres fædre og onkler ville blive sendt ud over landets grænser for at dø i en håbløs krig. At det betød en udstrakt grad af isolation fra regionens politiske udvikling, var man ikke så kede af.

\section{Sprækker $\mathrm{i}$ isolationen}

Men allerede i løbet af 1970'erne og 80 'erne kom de første sprækker i denne om ikke selvvalgte, så politisk bekvemme efterkrigsisolation i forhold til nabolandene.

I 1972 og 1978 blev der efter Nixon-chokket, hvor USA pludselig gik i dialog med det kommunistiske Kina, underskrevet historiske aftaler mellem Japan og Kina om fred, samarbejde og gensidig anerkendelse. Både turister, studerende og forretningsmænd begyndte at rejse frem og tilbage mellem de to lande.

Dengang bestræbte de generationer af politikere, der var ved magten i begge lande, sig på at skabe en atmosfære af forsoning mellem de to lande. Der blev dengang i gensidig forståelse talt og skrevet så lidt som muligt om de territoriale stridigheder og krigshistoriske traumer, som vi siden hen har hørt så meget om.

Også i forhold til Sydkorea var der tegn på, at årtiers isolation var på vej til at blive erstattet af samtale og samarbejde. I 1998 stod Sydkoreas daværende præsident, Kim Dae-jung, på talerstolen i det japanske parlament, og på udmærket japansk, som han havde lært i skolen, da han som dreng voksede op i et Korea, der dengang var en del af det kejserlige japanske imperium, erklærede, at nu var det tid for de to folk og de to lande til at se fremad i stedet for tilbage.

Det blev starten på en periode, hvor japansk og koreansk kultur krydse- 
de grænser i højere grad end tidligere, og hvor de to lande i 2002 med hiv og sving og en del mislyde sammen arrangerede verdensmesterskaberne i fodbold.

Det er med andre ord ingen naturlov, at Japan skal være på så anspændt fod med sine nærmeste nabolande, som landet har været i de seneste år og allermest under Shinzo Abe. Det er faktisk ikke ret længe siden, at tonen var helt anderledes.

\section{Politisk afpresning}

Når Japans forhold til Kina og begge Koreaer i de sidste femten år er gået i baglås, og når tidligere tiders totale isolation i perioder er vendt tilbage, er det ikke udelukkende Japans egen skyld.

\section{Den aktuelle isolation og det anspændte forhold til nabolan- dene skyldes unægtelig også den politik, som Japan selv, især under den nuværende regering, har ført.}

Der har hele tiden været dele af de kinesiske og koreanske ledelser, som i den regionale magtpolitik ser en interesse $i$ at fastholde Japan i den politiske og militære skammekrog, hvor landet efter krigen blev placeret.

Ethvert japansk forsøg på at revidere forfatningen er gennem årene automatisk blevet beskyldt for at være et udtryk for militarisme og revanchisme, og enhver dum bemærkning af gamle konservative politikere om krigen blev i 1980'erne og 90'erne beskyldt for at være udtryk for, at Japan som sådan aldrig har sagt undskyld for aggression og krigsforbrydelser under krigen - hvilket det officielle Japan jo faktisk har gjort mange gange.

Japanere fra højre til venstre er trætte af, at kineserne og koreanerne tilsyneladende kun hører, hvad de ønsker at høre fra japansk side - og at de bliver ved med at bruge krigsårene til politisk afpresning over for Tokyo.

Men det er bestemt også Japans egen skyld. Den aktuelle isolation og det anspændte forhold til nabolandene skyldes unægtelig også den politik, som Japan selv, især under den nuværende regering, har ført.

\section{Historisk begrundet mistillid}

Japan har reelt gjort meget lidt for at fjerne nabolandenes skepsis og ubehag ved forsøgene på at give Japan en højere militær og sikkerhedspolitisk profil i regionen og bestræbelserne på at sætte spørgsmålstegn ved sejrherrernes version af krigshistorien. Bestræbelserne udspringer hos politikere og meningsmagere på den konservative og neonationalistiske fløj, men omfatter i dag store dele af den offentlige diskurs i Japan. Kinesere og koreanere kan bare blande sig udenom, hører man tit i Japan fra såvel politikere som menigmand.

Der er mange dele af efterkrigstidens fortælling om Anden Verdenskrig i Asien, som stadig har sit afsæt i den censurerede fortælling, som sejrherrerne og den amerikanske besættelsesmagt i Japan formidlede til omverdenen i månederne og årene efter krigen, så der er al mulig grund til, at faghistorikere sætter sig ned og 
på tværs af nationaliteter og politiske skel stiller skarpt på, hvad der skete og ikke skete under den krig.

Men den nuværende japanske regering gør bestemt ikke disse bestræbelser nemmere, når den ved nogle lejligheder forsøger at benægte, hvad ikke kan benægtes.

Der er så mange vidneudsagn om, at den kejserlige japanske hær var involveret i rekrutteringen af såkaldte trøstekvinder, tvangsprostituerede unge koreanske og kinesiske piger ved den japanske front, at det skaber mistro og får debatten til at gå i hårdknude, når japanske diplomater rundt omkring i verden inviterer os journalister ud til timelange belæringer om, at det ikke var tilfældet.

Og der er så mange vidneudsagn om, at der fandt en blodig massakre sted, da den kinesiske by Nanjing blev indtaget af japanske styrker i december 1937, at det ligeledes skaber mistro og hårdknude, når Abe-regeringens diplomater møder op ved forlag i fremmede lande og kræver, at de nedskriver antallet af dræbte i forlagets udgivelser om massakren. Der var næppe 300.000 dræbte, som det i dag hedder i officiel kinesisk historieskrivning, men en massakre var det.

Denne historisk begrundede mistillid forværres på flere punkter af

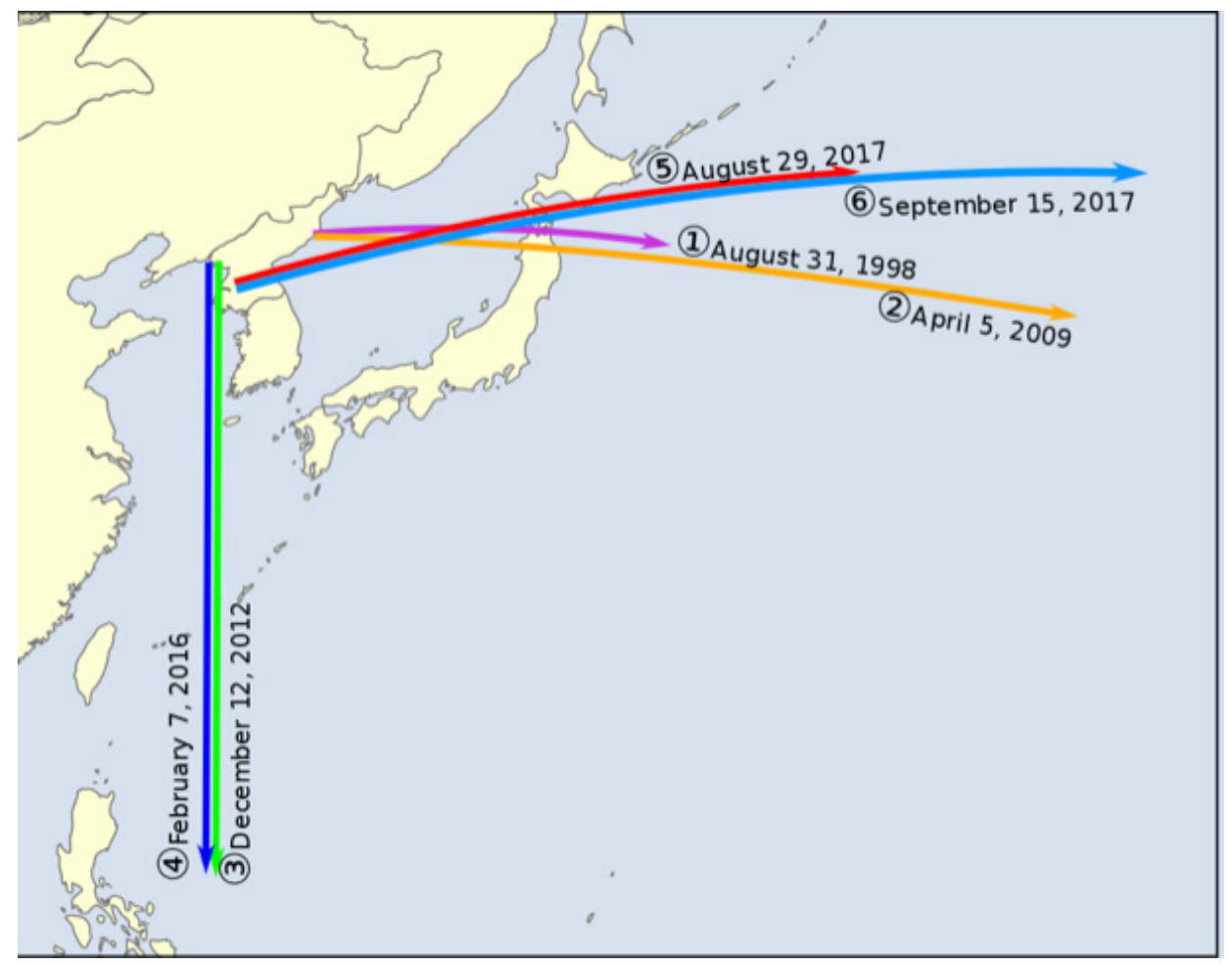

ILL: Phoenix 7777 via Wikimedia Commons 
den politik, som Japan fører i aktuelle spørgsmål.

\section{Japan på sidelinjen}

I den stemning af fred og forsoning, der pludselig i foråret greb hele regionen i forhold til Nordkorea, efter at landets leder, Kim Jong-un, i sin nytårstale havde lagt op til dialog og atomnedrustning, placerede Shinzo Abes Japan sig alene på sidelinjen, hvorfra man surmulende signalerede, at man helst ville fortsætte en politik med mindre dialog og mere 'maksimalt pres’ på Nordkorea.

Japan, som få måneder forinden havde oplevet to nordkoreanske testmissiler flyve hen over den nordlige del af landet, havde legitime interesser $\mathrm{i}$ at tvinge Nordkorea til ikke kun at stoppe udviklingen af mellemdistanceraketter, men også afskaffe sine kortrækkende raketter, der kan nå Japan, men som de andre lande bestemt ikke så ud til at prioritere højt i forhandlingerne med Nordkorea. På det punkt var der grund til at surmule.

Men Japan gjorde ondt værre ved stædigt at føre den gamle strid i marken om de bortførelser af unge japanere til Nordkorea, som nordkoreanske agenter gennemførte i 1970'erne og 80'erne, og som aldrig er fuldt opklaret. Japan kræver en fuld afdækning af sagerne, mens Nordkorea hævder, at man for længst har sagt undskyld og givet alle de oplysninger, man er i besiddelse af.
USA's og Sydkoreas præsidenter måtte love Shinzo Abe at nævne bortførelserne ved deres topmøder med Kim Jong-un. Men meget mere end at nævne dem skal man ikke regne med, at de har gjort. Der var større strategiske interesser på spil, og til de andre landes irritation virkede det, som om Japan slet ikke havde øje for det.

I debatten i Japan om fremtidens sikkerhedspolitik gentages det gang på gang, især af Abe-regeringen, at Japan befinder sig i en langt 'alvorligere sikkerhedspolitisk situation' end tidligere
- hvilket er fuldkommen sandt.

Dels har man i de senere år kunnet betragte det fjendtlige Nordkorea, som for alle japanere i den nordligste del af landet er det nærmeste naboland, men som Japan hverken har diplomatiske forbindelser med eller har anerkendt som stat, med stor dygtighed og succes anskaffe sig atomvåben og bruge det at være blevet en atommagt politisk i forhold til omverdenen.

Dels - og på længere sig måske endnu mere betydningsfuldt - har Kinas økonomiske vækst, øgede magt og aggressive politik i nogle områder af regionen undergravet fundamentet for efterkrigstidens pacifistiske og isolationistiske 'fred for den øvrige verdens ufred' i Japan.

\section{Andenviolin til Kina}

Mens et fattigt Kina i 1970'erne og 80 'erne sundede sig efter et endnu me- 
re isolationistisk årti under kulturrevolutionen, så Japans elite deres land som frontfigur, inspirator og leder af fremtidens økonomiske udvikling i det øvrige Asien - stadig uden militære magtmidler, der dengang ikke syntes nødvendige under atomparaplyen. Men nu må den samme elite modstræbende søge efter en helt anden rolle til sig selv som nogle gange rival nogle gange partner, men altid andenviolin til et langt stærkere Kina, som år efter år for alvor befæster sin dominans i regionen på alle felter, også militært.

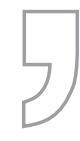

Hele efterkrigstidens politiske og sikkerhedspolitiske drejebog går ud fra USA's tilstedeværelse og den forjættede sikkerhedsaftale. Ingen kan rigtigt forestille sig en fremtid uden.

Samtidig dækker formuleringen med den 'alvorligere sikkerhedspolitiske situation' over en realpolitisk erkendelse af, at forfatningen, den amerikansk-japanske sikkerhedsaftale og atomparaplyen hele tiden har været resultater af en speciel historisk situation lige efter verdenskrigen, hvor det vigtigste for hele systemets faddere var at dæmme op over for en eventuel fremtidig ny militarisme i Japan.

Det bliver sværere og sværere at forestille sig, at dette system kan vare evigt - også selv om store dele af såvel elite som befolkning i Japan i mellemtiden er blevet godt tilpas med arrangementet. Der kommer en dag, hvor det ikke længere er sandsynligt, at USA vil komme Japan til hjælp ved en hvilken som helst begrænset militær konfrontation med et naboland. Og hvad gør Japan så?

\section{En fremtid uden USA}

Denne skepsis i Japans politiske cirkler over for USA's vilje til at leve op til de gamle aftaler, hvis for eksempel Kina og Japan roder sig ud i et kortvarigt militært sammenstød om de klippeøer nord for Taiwan, som japanerne kalder Senkaku, og kineserne kalder Diaoyu, og som begge parter hævder er en historisk del af deres land, er en tendens, som var tydelig længe før Donald Trumps valg til amerikansk præsident i november 2016. Men den er selvfølgelig blevet mere udtalt som en konsekvens af Trumps 'America First'-politik. Hele det japanske politiske establishment forbereder sig mere eller mindre åbent på en tid uden USA eller med mindre USA, og debatten om en revision af fredsforfatningen skal ses i det lys. Den er skrevet af udlændinge, den er skrevet i en helt anden tid, og det er ikke så sært, at mange i Japan godt kunne tænke sig en forfatning, der er deres egen, og som sætter nogle meningsfyldte spilleregler for landets ageren i nutiden.

I sommeren 2014 fik Abe-regeringen efter store protester og moddemonstrationer vedtaget en ny tolkning af forfatningen, som gør det muligt for Japan at deltage i 'kollektivt selvforsvar', dvs. deltage i aktioner med det formål at forsvare alliancepartnere mod angreb. Omfortolkningen var en indledende øvelse til det sæt sikkerhedspolitiske reformer, der udmøntede dem i praksis, og som efter endnu større protester blev vedtaget året efter. Men det er vigtigt at under- 
strege, at Abe-regeringens oprustning er begrænset, og at japanske soldaters muligheder for at operere uden for landets grænser stadig er uhyre begrænsede.

Meningsmålinger viser i foråret 2018 , at et flertal af japanske vælgere gerne på længere sigt vil have en ny forfatning, men ikke under Shinzo Abe. Mange vil gerne have en forpligtelse med i en ny forfatning til at bevare de gode sider af efterkrigstidens pacifisme, der for mange er blevet en del af japansk selvforståelse - og de ved, at det netop er denne pacifisme, Abe-regeringen gerne ser et opgør med.

Mens man bereder sig på en tid uden USA, gør alle parter sig imidlertid stor umage for at fastholde amerikanerne i så aktiv en rolle i regionen som muligt. Hele efterkrigstidens politiske og sikkerhedspolitiske drejebog går ud fra USA's tilstedeværelse og den forjættede sikkerhedsaftale. Ingen kan rigtigt forestille sig en fremtid uden.

Samtidig forsøger Japan, især siden Shinzo Abes tiltræden som regeringschef i december 2012, at føre et aktivt og udfarende diplomati i Sydøstasien, Indien, Afrika og selv det fjerne Europa for at skaffe sig samarbejdspartnere i et målrettet forsøg på at dæmme op - ikke at inddæmme, for det ved man godt er umuligt - over for Kinas øgede politiske, økonomiske og militære rækkevidde.

Og det er denne indsats, som ville kunne være mere effektiv, hvis ikke Abe-regeringens indbyggede konservatisme, traditionelle isolationisme og overdrevne fokus på historien så ofte belaster tillidsforholdet i forhold til andre landes repræsentanter. 